\title{
Quantifying responses of net primary productivity to individual agricultural land transitions in drylands
}

\author{
Ning Pan ${ }^{1}$, Shuai Wang ${ }^{2}$, Yanxu Liu ${ }^{3}$, Ting Hua ${ }^{3}$, Junze Zhang ${ }^{1}$, Feng Xue ${ }^{1}$, and Bojie Fu ${ }^{1}$ \\ ${ }^{1}$ Beijing Normal University \\ ${ }^{2}$ Research Center for Eco-Environmental Sciences, Chinese Academy of Sciences \\ ${ }^{3}$ Beijing Normal University
}

June 15, 2020

\begin{abstract}
There is limited understanding about agricultural land dynamic across global drylands and the impacts of different agricultural land transitions on ecosystem productivity changes. This study attempted to fill this gap by examining the agricultural land changes and net primary productivity responses in drylands. A data-driven assessment of the effects on the ecosystem productivity of individual agricultural land displacement was carried out using three methods: the mean difference method, a newly introduced ridge-regression method, and a proposed method based on actual change excluding climate impact. Increases in productivity were accompanied by agricultural land transitions from natural land covers, expected forests. The agriculture expansion mainly replaced sparse vegetation and grassland, and increased the overall productivity of the dryland ecosystem. Mean difference method and ridge-regression method over overestimated the NPP increase caused by agricultural land expansion. Land use change contributed more than $70 \%$ to increase in net primary productivity in new agricultural area. But land use change effects less on total productivity in drylands than climate change. Monitoring agricultural land dynamics and distinguishing productivity changes caused by different agricultural land transitions is helpful to the targeted management and sustainable development of agriculture in drylands.
\end{abstract}

\section{Introduction}

Covering about 41 percent of the Earth's land surface, drylands are home to an estimated 2.5 billion people, about 90 percent of them in developing countries. The abundant and unique dryland ecosystem provides various functions and services that are essential for human survival and development (Reynolds et al., 2007; Huang et al., 2017). Vegetation net primary productivity (NPP) defines the rate at which all plants in an ecosystem produce net useful chemical energy, and is an important part of energy and material conversion within an ecosystem ( Zhao and Running, 2010; Zhang et al. , 2018). Humans influence NPP through transformation activities that improve production and livelihoods, of which land use/cover change (LUCC) is the most human-specific activity (Li et al., 2020). The increase in population and corresponding material demand has meant that the scope of human ecological impacts has considerably increased, which has brought many potential ecological and environmental problems (Ren and Zhou, 2018; Wang et al., 2020). The scarce precipitation and lack of water resources mean that the dryland ecosystem is extremely fragile and sensitive to LUCC (Huang et al., 2018). Under this globalization scenario, studying the impact of LUCC on NPP in drylands may help improve food supply and maintain ecosystem health.

Land use/cover change is the cumulative results of numerous natural and socio-economic factors that are related to human activities in time and space (Zak et al. , 2008; Mendoza et al. , 2011; Changet al. , 2018). 
Along with population aggregation and economic development, urban and agricultural expansions transform natural ecosystems into human-dominated or human-naturally coupled ecosystems (Hedal Kløverpris, 2009; Qiu et al. , 2015; Dadashpoor et al. , 2019). Among them, agricultural expansion is the main reason for the reduction in natural land cover types (Egeru et al. , 2011; Mao et al., 2017; Gibbs et al. , 2010; van Vliet, 2019). Agricultural changes are related to food supply and economic development, and have been studied from regional to global scales (Chen, 2017; Akinyemi and Mashame, 2018). However, agricultural land changes across global drylands have rarely been assessed.

Land use changes lead to dramatic alterations in ecosystem structure and processes, which subsequently influence ecosystem services (Cherubiniet al. , 2018; Chen et al., 2019; Zhang et al., 2019; Huang et al. , 2020). Studies have shown that both deforestation and urbanization reduce the NPP of ecosystems (Zhanget al. , 2018). The correlation analysis of land use intensity and ecosystem services in previous studies can only qualitatively reveal the impact of specific land use changes on NPP, while the quantitative change NPP changes related to individual land transitions have been ignored or not effectively assessed (Zhang et al., 2018; Chen et al., 2019). Confusing the impact of all changes of a certain land use on environmental change may lead to sub-optimal adaptation strategies, especially on a large scale (Huang et al., 2020). The potential impacts of different land cover transitions on energy flux were quantified based on ridge-regression by Duveiller et al. (2018). However, this potential impact does not accurately represent the actual NPP changes resulting from land use change. The purpose of this study is to propose a method for estimating the impact of different agricultural land transitions on NPP based on actual changes.

This study aims to monitor agricultural land dynamics in drylands and accurately assess the impact of individual agricultural land transitions on NPP. Agricultural land changes in drylands between 1992 and 2015 were analyzed. The NPP changes related to agriculture replacing different natural cover types were estimated by the difference in the mean values and ridge-regression. Furthermore, we also propose a new method based on the actual NPP variation that can identify the influence of different agricultural land transitions on NPP. The change in net primary production due to agricultural land dynaimics was estimated based sum of individual agricultural land transitions. Finally, impacts on ecosystem productivity of agricultural expansion from different sources, sub-regional land cover changes response to agricultural expansion, implications of dryland agricultural land dynamics, and comparison of productivity effects assessment methods are discussed.

\section{Materials and methods}

\subsection{Materials}

\subsubsection{Land cover dataset.}

The European Space Agency Climate Change Initiative land cover (ESA CCI LC) dataset was used to map land use and land cover changes (LUCC) across global drylands. The dataset combines the global daily surface reflectance data from five different satellite observation systems, and can maintain high levels of consistency over time. It has provided LC maps over a 24year period from 1992 to 2015 at a spatial resolution of $300 \mathrm{~m}$ (Defourny et al., 2017). In this study, the spatial resolution was resampled to $0.05^{\circ}$. These maps characterize the global surface using 37 land cover classes based on the United Nations Land Cover Classification System (UNLCCS), and were designed to overcome previous limitations and reduce uncertainty when representing land cover and LUCC in climate models (Poulter et al. , 2015; Li et al. , 2018). The highest accuracy values for agricultural areas, forests, urban areas, and barren land can be used to analyze agricultural and urban expansion in drylands.

The sub-pixel proportions of each land cover were provided by the Moderate Resolution Imaging Spectroradiometer Land Cover Climate Modeling Grid Product (MODIS MCD12C1). The MCD12C1 data provide a spatially aggregated version of the tiled MODIS Land Cover Type Product (MCD12Q1), which is created using supervised classification. The product covers 2001 to 2018, at a spatial resolution of $0.05^{\circ}$. The majo- 
rity land cover type percent map in 2015 under the International Geosphere-Biosphere Programme (IGBP) classification scheme was used to calculate the potential impact of the individual transitions in land cover on ecosystem productivity.

\subsubsection{Net primary productivity data}

MODIS Net Primary Productivity (NPP) product (MOD17A3) was used in this study. The NPP product was produced by the Numerical Terradynamic Simulation Group (NTSG) at the University of Montana, USA (UMT). NPP comes from gross primary productivity (GPP) minus maintenance respiration and growth respiration, and GPP is based on the leaf area index (LAI) or the fraction of photosynthetically active radiation (FPAR) derived from the Terra satellites (Zhao et al., 2005). It is available at a yearly temporal resolution for 2000-2015, with a spatial resolution of $1 \mathrm{~km}$. The NPP data was also resampled to a spatial resolution of $0.05^{\circ}$, which was consistent with the land cover data.

\subsection{Methods}

\subsubsection{Land cover reclassification and change analysis}

The land cover was reclassified into eight types so that it be analyzed based on a uniform classification scheme (Yang et al. , 2017; Huaet al. , 2018). These categories were forest, shrubland, grassland, sparse vegetation, barren land, agriculture (including when it is mixed in with natural vegetation), urban areas, and others (including water bodies, ice and snow, and wetland, etc.) (Table 1). In the land cover percent map, both sparse vegetation and barren land were classified as barren because the two categories were not distinguished in the IGBP scheme.

Transition matrices were created to record changes in land cover types over each 5-year period: 1995-2000, 2000-2005, 2005-2010, 2010-2015, and for the total period1995-2015. Each cell on the main diagonal of the matrix contains the surface area (unit: Mha) of each land cover type that remains unchanged during the analysis period, while the remaining cells contain the area of a given land cover type that changes to different types within the same period. These represent the LUCC dynamics. The intensity analysis was based on the transition matrices. From the perspective of system theory, intensity analysis evaluates the non-uniform degree of LUCC at the time interval, category, and transition levels (Aldwaik and Pontius, 2012). A hierarchical interpretation framework means that the intensity analysis can give a comprehensive understanding of LUCC processes and the interaction mechanism. This interpretive framework has been widely used in LUCC research (Zhou et al. , 2014; Da et al. , 2019). The time interval level can show whether the LUCC in a given time interval is relatively slow or rapid compared to the overall study period. The category level can show whether the gross loss and gross gain intensities for each type were relatively active or stable during a specific period. The transition level examines the intensity of the transition from one type to another.

\subsubsection{Assessment of theindividual land transition impacts on NPP}

Three methods were used to evaluate the impacts of individual agricultural land transitions on NPP. The first method was based on the average NPP between 2000 and 2015 for each land cover type. The difference between the average NPP for agriculture and another land cover type was regarded as the NPP change caused by the conversion of the land cover type to agriculture. The second was ridge-regression evaluation method developed by Duveiller et al. (2018). In this approach, the direct effects of land cover change considered were over a local moving window, and the indirect perturbations due to regional changes outside the window were ignored (Duveiller et al. , 2018; Huang et al. , 2020). The ridge-regression analysis was repeated for the entire dryland area so that the NPP response to agricultural land transitions in an arid environment could be determined. The windows where all the NPP values were zero (representing barren land) were excluded so that the barren land in the MCD12C1 data set could be matched with the sparse vegetation in the CCI 
dataset. The mean NPP changes for each agricultural land transition in all considered windows for drylands were calculated using the weighted mean (Huang et al. , 2020).

In addition, we propose a novel method to quantify the NPP change related to individual agricultural land transitions based on the difference between the actual NPP variation and the climate impact. Firstly, the study area was divided into the land cover unchanged area and the type transformed area. The NPP change in the unchanged area was considered to be the result of climate change while NPP changes in the type transformed area included both the NPP change caused by land cover change and the impact of climate change. The NPP change in land cover type X due to climate change was the difference between NPP at start and end of the study period in the type X unaltered area. The NPP values at the start and the end were the average over 5 years, respectively. Subsequently, different sources of new agriculture were discriminated. In area of new agriculture transformed from land cover type X, the actual NPP variation was calculated from the average NPP of the area at the start year minus that at the end year of the study period. Assuming climate change has the same effects on the unchanged area and the land cover transformed area, then the NPP change caused by transformation from land cover type $\mathrm{X}$ to agriculture is

$$
\overline{N P P_{\text {transform }}=N P P_{\text {fact }}-N P P_{\text {climate }} \quad(1)}
$$

where $N P P_{\text {fact }}$ and $N P P_{\text {climate }}$ are the actual NPP variation and the NPP effected by climate change, respectively. In an area where the land cover type changed, the relative contribution of the land cover change to the NPP change is:

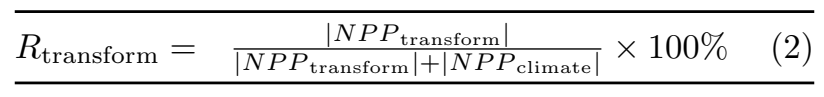

\subsubsection{Estimating net primary production changes}

The annual NPP trend was calculated by Sen's slope estimates, and its significance level was evaluated by the Mann-Kendall (MK) test (Wuet al. , 2008). The change in net primary production caused by agricultural land expansion was obtained by area weighting the NPP change. Then, the total primary production change resulting from the occupation of natural cover by agriculture is:

$$
\overline{P=\sum N P P_{i} \bullet A_{\mathrm{i}}(i=1,2,3, \ldots, \text { is the type number }) \quad(3)}
$$

where $i$ is the type number, $N P P_{i}$ is the NPP change caused by agricultural encroachment onto natural land cover type $i$, and $A_{i}$ is the area of new agriculture transformed from type $i$.

The method proposed by Hicke et al. (2004) was used to quantify net primary production changes across the whole dryland area, and to determine the contributions made by land cover change and climate change. For a certain land cover type, the difference in net primary production $(P)$ across the study period is calculated based on differences in area and $\operatorname{NPP}(S$ and $N P P$, respectively):

$$
P=S_{2} \times \mathrm{NPP}_{2}-S_{1} \times \mathrm{NPP}_{1}=S_{1} \times N P P+S \times \mathrm{NPP}_{1}+N P P \times S
$$

where $S_{1}, \mathrm{~S}_{2}$, andNPP,$\quad \mathrm{NPP}_{2}$ are the total area and mean NPP of the land cover type at the beginning and end of the study, respectively. Therefore, the change in net primary production consists of three parts. The first part $\left(S_{1} \times N P P\right)$ represents the production change caused by the change in NPP when the area of the cover type is unchanged. Assuming that NPP remains unchanged, then the change in production caused by land cover change is the second part $\left(S \times \mathrm{NPP}_{1}\right)$. The third part $(N P P \times S)$ shows the production change caused by the interaction between climate change and land cover change. The relative contribution 
$\left(R_{i}\right)$ of each part $\left(P_{i}\right)$ to net primary production is

$$
\overline{R_{i}=\frac{\left|P_{i}\right|}{\sum\left|P_{i}\right|} \times 100 \% \quad(5)}
$$

\section{Results}

\subsection{Relationship between land cover and net primary productivity}

A total of $18.8 \%$ of the global 6.4 billion hectares of drylands is classified as agricultural land, including mixtures with natural vegetation. The remaining $81.2 \%$ is classified as forest (9.3\% of total dryland area), shrubland $(15.6 \%)$, grassland $(14.5 \%)$, sparse vegetation $(9.8 \%)$, barren land $(28.4 \%)$, urban areas $(0.3 \%)$, and others (3.3\%) (Fig. 1a). The NPP gradient was related to vegetation coverage (Fig. 1b). Large differences in NPP existed between cover types, and the multi-year average NPPs for the five main types of natural cover in drylands was in the order: forest $\left.\left(0.45 \mathrm{~kg} \mathrm{C}^{2}\right] \mathrm{m}^{-2}[?] \mathrm{y}^{-1}\right)$, shrubland $\left.\left(0.26 \mathrm{~kg} \mathrm{C}^{-1}\right] \mathrm{m}^{-2}[?] \mathrm{y}^{-1}\right)$, grassland $\left.\left(0.18 \mathrm{~kg} \mathrm{C}^{2}\right] \mathrm{m}^{-2}[?] \mathrm{y}^{-1}\right)$, sparse vegetation $\left.\left(0.10 \mathrm{~kg} \mathrm{C}^{2}\right] \mathrm{m}^{-2}[?] \mathrm{y}^{-1}\right)$, and barren land $\left.\left(0.01 \mathrm{~kg} \mathrm{C}^{2}\right] \mathrm{m}^{-2}[?] \mathrm{y}^{-1}\right)$. The frequency distributions for the dryland land cover NPPs (Fig. 1) showed agricultural NPP values were only smaller than forest NPPs and were mainly distributed in the range $0.15^{\sim} 0.4 \mathrm{~kg} \mathrm{C}[?] \mathrm{m}^{-2}[?] \mathrm{y}^{-1}$. The multi-year average NPP for agriculture was about $0.30 \mathrm{~kg} \mathrm{C}\left[? \mathrm{~m}^{-2}[?] \mathrm{y}^{-1}\right.$, which was higher than for most of natural land types in drylands, except for forest.

\subsection{Agricultural changes andencroachment on natural land cover}

A total of 41.0 Mha of new agriculture appeared across global drylands between 1995 and 2015. The intensity of agricultural expansion declined. The agricultural land gains was almost the same as losses during 2010 - 2015, both of which were relatively dormant (Fig. 2a). Agricultural expansion was the direct reason for the reduction in natural cover. Across all the dryland, the net area of agriculture encroached the natural land covers is sparse vegetation ( $\sim 16 \mathrm{Mha})$, grassland ( $\sim 12 \mathrm{Mha})$, shrubland ( $\sim 10 \mathrm{Mha})$ and forest (5 Mha) in order (Fig. 2b). $97 \%$ of the net loss in agriculture was due to urbanization.

Large differences existed between global regions (Fig. 3). Agriculture in Asian drylands were mainly located in Central Asia, and were mostly found in sparse vegetation areas, followed by grassland and barren land. New dryland agricultural areas in Africa mainly encroached on shrubland and grassland, whereas that in Australia mainly encroached on shrubland, which were concentrated in the eastern part of the country. $75 \%$ of new agricultural areas in South America came from forests. The agricultural expansion in drylands of North America and Europe were relatively small, and mainly occupied grassland and sparse vegetation, respectively. However, the gain area for agriculture from each natural land cover was not always greater than the loss area at the regional scale. In Australia, Europe, and North American drylands, the forest area gained from abandoned agricultural areas was larger than the forest lost to new agricultural areas. In addition, some abandoned agricultural areas became shrubland in the drylands of Europe.

\subsection{Net primary productivity change in Agricultural land}

In areas of agricultural expansion, NPP was affected when agriculture replaces natural cover (Fig. 4a). According to the average NPP for each cover type, the average NPP for agriculture was $0.15 \mathrm{~kg} \mathrm{C}[?] \mathrm{m}^{-2}[?] \mathrm{y}^{-1}$

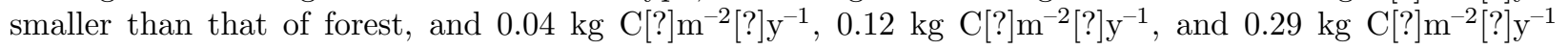
larger than that of shrubland, grassland, and sparse vegetation, respectively. The ridge regression assessment showed that agriculture replacing forest reduced NPP by $0.44 \mathrm{~kg} \mathrm{C}^{-}\left[\mathrm{m}^{-2}[?] \mathrm{y}^{-1}\right.$, but agriculture replacing shrubland and sparse vegetation increased NPP by $0.01 \mathrm{~kg} \mathrm{C}[?] \mathrm{m}^{-2}[?] \mathrm{y}^{-1}$ and $0.33 \mathrm{~kg} \mathrm{C}[?] \mathrm{m}^{-2}[?] \mathrm{y}^{-1}$, respectively. After subtracting the effect of climate change from the actual change in the transformation 
area, converting forest to agriculture reduced NPP by $0.036 \mathrm{~kg} \mathrm{C}[?] \mathrm{m}^{-2}[?] \mathrm{y}^{-1}$; and the conversion of shrubland, grassland, and sparse vegetation to agriculture increased NPP by $0.013 \mathrm{~kg} \mathrm{C}[?] \mathrm{m}^{-2}[?] \mathrm{y}^{-1}, 0.003 \mathrm{~kg}$ $\mathrm{C}[?] \mathrm{m}^{-2}[?] \mathrm{y}^{-1}$, and $\left.0.048 \mathrm{~kg} \mathrm{C}^{2}\right] \mathrm{m}^{-2}[?] \mathrm{y}^{-1}$, respectively. These results confirmed that there was an increase in NPP when natural land cover types other than forestry were converted to agriculture in drylands.

If the new agricultural areas since 2005 are used as an example, then the results showed that NPP underwent a transitional change from a decreasing trend to an increasing trend after the land was converted to agriculture (Fig. 4b). They showed that the overall impact of agriculture replacing natural cover on NPP was to increase it. The slope of increasing average NPP values for new agricultural land was $2.4 \mathrm{~g} \mathrm{C} \mathrm{m}^{-2} \mathrm{y}^{-2}$, which is higher than for the original agricultural area $\left(0.7 \mathrm{~g} \mathrm{C} \mathrm{m}^{-2} \mathrm{y}^{-2}\right)$. It means that land cover change increased the average NPP of agricultural expansion areas. Furthermore, in new agricultural areas, the change in cover type had a greater impact on NPP change than climate change, with a relative contribution of more than $70 \%$.

\subsection{Agricultural impact on net primary production across all drylands}

The change in net primary production was obtained by area weighting the change in NPP during the transition process (Table 2). From 2000 to 2015, the forest, shrubland, grassland, sparse vegetation and barren areas converted to agriculture were 1.38 Mha, 3.89 Mha, 5.94 Mha, 7.02 Mha, and 2.37 Mha, respectively. The calculation results based on the average NPP difference and the ridge regression were about 27 and 25 $\operatorname{Tg~C}\left(1 \mathrm{Tg} \mathrm{C}=10^{12} \mathrm{~g} \mathrm{C}\right)$, respectively, while the estimated results based on the actual transition were 2.4 $\mathrm{Tg}$ C. The three calculation results all showed agricultural expansion increased total net primary production for the dryland ecosystem.

The NPP of all land covers in drylands increased by varying degrees during $2000-2015$ (Table 3). The average NPP across all drylands increased by $5 \mathrm{gC}[?] \mathrm{m}^{-2}$, and the total net primary production increased by $365 \mathrm{Tg} \mathrm{C}$. Agriculture NPP increased by $6 \mathrm{gC}[?] \mathrm{m}^{-2}$, which is more than that of average increase in drylands. Net primary production of dryland agroecosystems increased $108 \mathrm{Tg} \mathrm{C}$, and contributed $30 \%$ to total increase in dryland ecosystems. Net primary production in original agricultural areas has increased by $69 \mathrm{Tg} \mathrm{C}$, and area expansion has increased agricultural production by $38 \mathrm{Tg} \mathrm{C}$. The increased production through agricultural expansion contributed to $35 \%$ of total increased production in dryland agroecosystems.

\section{Discussion}

\subsection{Impacts on ecosystem productivity of agricultural expansion from differ- ent sources}

Results revealed that agricultural expansion at the expense of forest reduces ecosystem NPP, while converting grassland or sparse vegetation to agriculture has been shown to increase ecosystem NPP. The ecosystem productivity changes mean that the agricultural expansion breaks the energy balance of the original ecosystem. The difference of productivity changes distinguishes the impact of agricultural expansion from different sources on the ecosystem services. Agricultural expansion from forest area has led to increased $\mathrm{CO}_{2}$ emissions and has reduced carbon sinks, which affects the ecosystem service of carbon storage (Zhang, 2019). These agricultural areas consume less water and soil fertility than original natural state, but increase the risk of soil erosion by water or wind. Agricultural expansion from other land cover areas can accelerate carbon cycling. These agricultural improvements increase the ground biomass of the ecosystem, but have another negative impact on water and soil conservation. The NPP increase is mainly due to human managements, such as fertilization, irrigation, and high-density planting (Foley et al. , 2011; Zhou et al ., 2011; Lambin et al. , 2013), which means more consumption of water resources and soil fertility (Teixeiraet al. , 2014; Sheikhy et al. , 2017). Further, irrigation and long-term chemical fertilization will cause soil fertility failure, 
such as salinization, compaction and acidification (Zhang et al., 2014). Therefore, the impact of agricultural expansion from different sources on ecosystem services should be treated differently.

\subsection{Sub-regional land cover changes response to agricultural expansion}

Dryland agricultural expansion mainly invades sparse vegetation and grassland according to our result, which is different from agricultural encroachment in humid areas. Gibbs et al. (2010) pointed out that tropical forest is the main source of global new agriculture, mainly due to the agricultural expansion in humid areas. Dryland populations account for $36 \%$ of the global population, and agricultural expansion in drylands has accounted for $28 \%$ of global agricultural expansion over the past 20 years. This suggests that the land pressure brought about by population growth and consumption increase is mainly exerted on humid areas. The local ecological environment affects agricultural land dynamics and explains the regional differences in the impact of agriculture on natural land types. Previous researchers have suggested that agriculture expansion tends to occur in areas with similar or more fertile ecological environments, while avoiding areas with poor ecological conditions (such as high altitude, steep slopes, and low available water) (Spera et al. , 2014; Chen, 2017). Therefore, agricultural expansion mainly invades fertile forest areas in humid areas. The low exposure area of forest makes agricultural expansion be dominated by invading other land covers in drylands. Forest areas only account for $9.3 \%$ of the dryland, and these are mainly distributed at the margins of tropical forests in South America and at high latitudes in Asia and North America. Therefore, new agricultural areas have mainly invaded forests in South American drylands, unlike that in drylands of other continents. Although agricultural expansion is globally, the natural land cover losses caused by agricultural expansion was sub-regional due to local environment.

\subsection{Implications of dryland agricultural land dynamics}

The result show that agricultural expansion in drylands has slowed down from 1995 to 2015 . For one reason, human beings pay more attention to the protection of the natural environment. Corresponding policies, such as revegetation and 'Grain for Green', have been implemented in many regions and achieved results (McVicar et al., 2007; Geng et al., 2019). For another, increased agricultural productivity caused by technological development and climatic change has saved land. The increase in overall dryland NPP reflects the positive effects of climate change on ecosystem productivity in drylands. And the contribution of climate change is greater than that of LUCC on net primary production of both whole dryland and most individual land covers (Table 3 ).

At present, the area dynamics for agriculture are relatively stable, which means that limited agricultural area will bear more production pressure under the pressure of increasing population. Globally, the growing demand for food caused by population growth is the root cause of agricultural expansion (Tilman et al. , 2011). At the same time, human demand for settlements has led to rapid urban expansion and the subsequent loss of large amounts of original agricultural land (Suet al. , 2011; Jiang et al. , 2013; Shi et al. , 2016). Therefore, agriculture has expanded into natural areas to meet increased food demand, and to make up for lost crop production (van Vliet, 2019). Table 3 shows that the main reason for the increase in net primary production for agriculture across all dryland is not area expansion, but productivity increase. The NPP in dryland agriculture has exceeded most vegetation productivity in its natural state, and is continues increasing, so that more productivity means more water and soil resources will be consumed. There should be a greater focus on how to better manage existing agriculture to mitigate the conflict between increasing agricultural productivity and sustainable development (Bhardwaj et al., 2011; Tilman et al., 2011; Lambinet al., 2013; Zou et al., 2013).

\subsection{Comparison of productivity effects assessment methods}

All three methods confirmed the promotion of agricultural expansion on productivity in drylands, but the estimated effect degrees differed in the results. Relatively speaking, the average NPP difference and the 
ridge regression method overestimated the NPP changes caused by agricultural expansion. Both methods consider that the NPP in the new agricultural area is the same as NPP in the original agricultural area. In fact, the NPP in the new agricultural area has not reached the level of the original agricultural NPP, which can be confirmed from Figure 5. Similarly, assessment of the agricultural production increase due to area expansion using method of Hicke et al. (2004) is overestimated. Therefore, the method proposed in this paper more accurately estimates the impact of agricultural expansion on NPP.

\section{Conclusions}

This study analyzed the agricultural land dynamics and NPP changes related to different agricultural land transition. Dryland agriculture expanded $41 \mathrm{Mha}$, and the expansion slowed down from 1995 to 2015. Agricultural NPP in dryland exceeds NPP of most land cover except forests. The agricultural expansion mainly encroached sparse vegetation and grassland, and has increased total productivity of the drylands. The comparison shows the proposed method can more accurately estimate the NPP increase caused by agricultural expansion than average NPP difference and ridge-regression method. Climate change, rather than agricultural expansion, is not the main reason for increased agricultural production. Estimating NPP changes for different agricultural land transitions can more accurately estimate the impact of agricultural expansion on the overall ecosystem NPP. It is also conducive to distinguish the agricultural impacts on different ecosystem services, and make targeted response for sustainable development of agriculture.

\section{Acknowledgments}

This work was supported by the National Key Research and Development Program of China [grant number 2017YFA0604701], the National Natural Science Foundation of China [grant number 4171101213], and the Fundamental Research Funds for the Central Universities. We thank International Science Editing for providing language help.

\section{Conflict of Interest Statement}

The authors declare that they have no known competing financial interests or personal relationships that could have appeared to influence the work reported in this paper.

\section{References}

Akinyemi, F. O., \& Mashame, G. (2018). Analysis of land change in the dryland agricultural landscapes of eastern Botswana. Land Use Policy, 76, 798-811. doi:10.1016/j.landusepol.2018.03.010 Aldwaik, S. Z., \& Pontius, R. G. (2012). Intensity analysis to unify measurements of size and stationarity of land changes by interval, category, and transition. Landscape and Urban Planning, 106(1), 103-114. doi:10.1016/j.landurbplan.2012.02.010 Bhardwaj, A.K., Jasrotia, P., Hamilton, S.K., \& Robertson, G.P., (2011). Ecological management of intensively cropped agro-ecosystems improves soil quality with sustained productivity. Agriculture Ecosystems \& Environment 140, 419-429, doi: 10.1016/j.agee.2011.01.005 Chang, Y., Hou, K., Li, X., Zhang, Y., \& Chen, P. (2018). Review of Land Use and Land Cover Change research progress. IOP Conference Series: Earth and Environmental Science, 113. doi:10.1088/17551315/113/1/012087 Chen, A. (2017). Spatially explicit modelling of agricultural dynamics in semi-arid environments. Ecological Modelling, 363, 31-47. doi:10.1016/j.ecolmodel.2017.08.025 Chen, W., Chi, G., \& $\mathrm{Li}, \mathrm{J}$. (2019). The spatial association of ecosystem services with land use and land cover change at the county level in China, 1995-2015. Science of the Total Enviromrnt, 669, 459-470. doi:10.1016/j.scitotenv.2019.03.139 Cherubini, F., Huang, B., Hu, X., Tölle, M. H., \& Strømman, A. H. (2018). Quantifying the climate response to extreme land cover changes in Europe with a regional model. Environmental Research Letters, 13(7). doi:10.1088/1748-9326/aac794 Da, F., Chen, X., \& Qi, J. (2019). Spatiotemporal Characteristic of Land Use/Land Cover Changes in the Middle and Lower Reaches of Shule River Basin Based on an Intensity 
Analysis. Sustainability, 11(5). doi:10.3390/su11051360 Dadashpoor, H., Azizi, P., \& Moghadasi, M. (2019). Land use change, urbanization, and change in landscape pattern in a metropolitan area. Science of the Total Enviromrnt, 655, 707-719. doi:10.1016/j.scitotenv.2018.11.267 Dobrovolski, R., Loyola, R.D., Guilhaumon, F., Gouveia, S.F., \& Diniz-Filho, J.A.F., (2013). Global agricultural expansion and carnivore conservation biogeography. Biological Conservation, 165, 162-170, doi: 10.1016/j.biocon.2013.06.004 Duveiller, G., Hooker, J., \& Cescatti, A. (2018). The mark of vegetation change on Earth's surface energy balance. Nature communications, 9, 679. doi:10.1038/s41467-017-02810-8 Foley, J.A., Ramankutty, N., Brauman, K.A., Cassidy, E.S., Gerber, J.S., Johnston, M., Mueller, N.D., O'Connell, C., Ray, D.K., West, P.C., Balzer, C., Bennett, E.M., Carpenter, S.R., Hill, J., Monfreda, C., Polasky, S., Rockstrom, J., Sheehan, J., Siebert, S., Tilman, D., \& Zaks, D.P., (2011). Solutions for a cultivated planet : Addressing our global food production and environmental sustainability challenges. Nature, 478, 337-342. Geng, Q.L., Ren, Q.F, Yan, H.M., et al., (2019). Target areas for harmonizing the Grain for Green Programme in China's Loess Plateau.Land Degradation \& Development, 31, 325-333, doi: 10.1002/ldr.3451 Egeru, A., Okello, P., Majaliwa, M. G. J., Mukwaya, P., \& Isubikalu, P. (2011). The Effect of Land use/cover change on Biomass Stock in Dryland Areas of Eastern Uganda. A case study of Olio Sub-county in Soroti District. Journal of Applied Sciences and Environmental Management, 14(4). doi:10.4314/jasem.v14i4.63280 Gibbs, H. K., Ruesch, A. S., Achard, F., Clayton, M. K., Holmgren, P., Ramankutty, N., \& Foley, J. A. (2010). Tropical forests were the primary sources of new agricultural land in the 1980s and 1990s. Proceedings of the National Academy of Sciences of the United States of America, 107(38), 16732-16737. doi:10.1073/pnas.0910275107 Hedal Kløverpris, J. (2009). Identification of biomes affected by marginal expansion of agricultural land use induced by increased crop consumption. Journal of Cleaner Production, 17(4), 463-470. doi:10.1016/j.jclepro.2008.08.011 Hicke, J.A., Lobell, D.B., Asner, G.P., (2004). Cropland area and net primary production computed from 30 years of USDA agricultural harvest data. Earth Interactions 8, 1-20, doi: 10.1175/1087-3562(2004)0082.0.CO;2 Hua, T., Zhao, W., Liu, Y., Wang, S., \& Yang, S. (2018). Spatial Consistency Assessments for Global Land-Cover Datasets: A Comparison among GLC2000, CCI LC, MCD12, GLOBCOVER and GLCNMO. Remote Sensing, 10(11). doi:10.3390/rs10111846 Huang, J., Li, Y., Fu, C., et al., (2017). Dryland climate: Recent progress and challenges. Reviews of Geophysics 55: 719-778, doi: 10.1002/2016RG000550 Huang K., Xia J.Y., Wang Y.P. et al., (2018). Enhanced peak growth of global vegetation and its key mechanisms. Nature Ecology and evolution 2: 1897-1905, doi: 10.1038/s41559-018-0714-0 Huang, B., Hu, X., Fuglstad, G. A., Zhou, X., Zhao, W., \& Cherubini, F. (2020). Predominant regional biophysical cooling from recent land cover changes in Europe. Nature communications, 11(1), 1066. doi:10.1038/s41467-020-14890-0 Jiang, L., Deng, X., \& Seto, K. C. (2013). The impact of urban expansion on agricultural land use intensity in China. Land Use Policy, 35, 33-39. doi:10.1016/j.landusepol.2013.04.011 Lambin, E. F., Gibbs, H. K., Ferreira, L., Grau, R., Mayaux, P., Meyfroidt, P., . . Munger, J. (2013). Estimating the world's potentially available cropland using a bottom-up approach. Global Environmental Change, 23(5), 892-901. doi:10.1016/j.gloenvcha.2013.05.005 Li, W., MacBean, N., Ciais, P., Defourny, P., Lamarche, C., Bontemps, S., . . Peng, S. (2018). Gross and net land cover changes in the main plant functional types derived from the annual ESA CCI land cover maps (1992-2015). Earth System Science Data, 10(1), 219-234. doi:10.5194/essd-10-219-2018 Li, F., Meng, J., Zhu, L., You, N. (2020). Spatial pattern and temporal trend of land degradation in the Heihe River Basin of China using local net primary production scaling.Land Degradation \& Development, 31, 518-530. doi: 10.1002/ldr.3468 Mao, D., Wang, Z., Wu, B., Zeng, Y., Luo, L., Zhang., B. (2017). Land degradation and restoration in the arid and semiarid zones of China: Quantified evidence and implications from satellites.Land Degradation \& Development, 29, 3841-3851. doi: 10.1002/ldr.3135 McVicar, T.R., Li, L., Van Niel, T.G., Zhang, L., Li, R., Yang, Q., Zhang, X., Mu, X., Wen, Z., Liu, W., Zhao, Y.A., Liu, Z., Gao, P., (2007). Developing a decision support tool for China's re-vegetation program: Simulating regional impacts of afforestation on average annual streamflow in the Loess Plateau. Forest Ecology and Management, 251, 65-81, doi: 10.1016/j.foreco.2007.06.025 Mendoza, M. E., Granados, E. L., Geneletti, D., Pérez-Salicrup, D. R., \& Salinas, V. (2011). Analysing land cover and land use change processes at watershed level: A multitemporal study in the Lake Cuitzeo Watershed, Mexico (1975-2003). Applied Geography, 31(1), 237-250. doi:10.1016/j.apgeog.2010.05.010 Poulter, B., MacBean, N., Hartley, A., Khlystova, I., Arino, O., Betts, R., . . Peylin, P. (2015). Plant functional type classification for earth system models: results from the European Space Agency's Land Cover Clima- 
te Change Initiative. Geoscientific Model Development, 8(7), 2315-2328. doi:10.5194/gmd-8-2315-2015 Ren, H., \& Zhou, G. (2020) Measuring the impacts of anthropogenic activities on Inner Mongolian temperate grassland.Land Degradation \& Development, 29, 2942-2950, doi:10.1002/ldr.3055 Reynolds, J.F., Stafford Smith, D.M., Lambin, E.F. et al., (2007). Global desertification: Building a science for dryland development. Science, 316(5826): 847-851, doi: 10.1126/science.1131634 Qiu, B., Li, H., Zhou, M., \& Zhang, L. (2015). Vulnerability of ecosystem services provisioning to urbanization: A case of China. Ecological Indicators, 57, 505-513. doi:10.1016/j.ecolind.2015.04.025 Sheikhy Narany, T., Aris, A. Z., Sefie, A., \& Keesstra, S. (2017). Detecting and predicting the impact of land use changes on groundwater quality, a case study in Northern Kelantan, Malaysia. Science of the Total Enviromrnt, 599-600, 844-853. doi:10.1016/j.scitotenv.2017.04.171 Shi, K., Chen, Y., Yu, B., Xu, T., Li, L., Huang, C., . . . Wu, J. (2016). Urban Expansion and Agricultural Land Loss in China: A Multiscale Perspective. Sustainability, 8(8). doi:10.3390/su8080790 Spera, S. A., Cohn, A. S., VanWey, L. K., Mustard, J. F., Rudorff, B. F., Risso, J., \& Adami, M. (2014). Recent cropping frequency, expansion, and abandonment in Mato Grosso, Brazil had selective land characteristics. Environmental Research Letters, 9(6). doi:10.1088/1748-9326/9/6/064010 Su, S., Jiang, Z., Zhang, Q., \& Zhang, Y. (2011). Transformation of agricultural landscapes under rapid urbanization: A threat to sustainability in Hang-Jia-Hu region, China. Applied Geography, 31(2), 439-449. doi:10.1016/j.apgeog.2010.10.008 Teixeira, Z., Teixeira, H., \& Marques, J. C. (2014). Systematic processes of land use/land cover change to identify relevant driving forces: implications on water quality. Science of the Total Enviromrnt, 470471, 1320-1335. doi:10.1016/j.scitotenv.2013.10.098 Tilman, D., Balzer, C., Hill, J., \& Befort, B. L. (2011). Global food demand and the sustainable intensification of agriculture. Proceedings of the National Academy of Sciences of the United States of America, 108(50), 20260-20264. doi:10.1073/pnas.1116437108 van Vliet, J. (2019). Direct and indirect loss of natural area from urban expansion. Nature Sustainability, 2(8), 755-763. doi:10.1038/s41893-019-0340-0 Wang, Y., Yue, H., Peng, Q., He, C., \& Bryan, B.A. (2020). Recent responses of grassland net primary productivity to climatic and anthropogenic factors in kyrgyzstan. Land Degradation \& Development, 1-17, doi: 10.1002/ldr.3623 Wu, H., Soh, L.K., Samal, A., \& Chen, X.H. (2008). Trend analysis of stream flow drought events in Nebraska. Water Resources Management, 22: 145-164, doi:10.1007/s11269-006-9148-6 Yang, Y., Xiao, P., Feng, X., Li, H., (2017). Accuracy assessment of seven global land cover datasets over China. ISPRS Journal of Photogrammetry and Remote Sensing, 125, 156-173, doi: 10.1016/j.isprsjprs.2017.01.016 Yang, Y., Xiao, P., Feng, X., \& Li, H. (2017). Accuracy assessment of seven global land cover datasets over China. ISPRS Journal of Photogrammetry and Remote Sensing, 125, 156-173. doi:10.1016/j.isprsjprs.2017.01.016 Zak, M. R., Cabido, M., Caceres, D., \& Diaz, S. (2008). What drives accelerated land cover change in central Argentina? Synergistic consequences of climatic, socioeconomic, and technological factors. Environment Management, 42(2), 181-189. doi:10.1007/s00267-0089101-y Zhang, F., Yushanjiang, A., \& Jing, Y. (2019). Assessing and predicting changes of the ecosystem service values based on land use/cover change in Ebinur Lake Wetland National Nature Reserve, Xinjiang, China. Science of the Total Enviromrnt, 656, 1133-1144. doi:10.1016/j.scitotenv.2018.11.444 Zhang, X. (2019). Multiple Cropping System Expansion: Increasing Agricultural Greenhouse Gas Emissions in the North China Plain and Neighboring Regions. Sustainability, 11(14). doi:10.3390/su11143941 Zhang, Y., Liu, Y., Zhang, Y., Liu, Y., Zhang, G., \& Chen, Y. (2018). On the spatial relationship between ecosystem services and urbanization: A case study in Wuhan, China. Science of the Total Enviromrnt, 637-638, 780-790. doi:10.1016/j.scitotenv.2018.04.396 Zhang, Z., Hu H., Tian F., Yao X., \& Sivapalan M. (2014). Groundwater dynamics under water-saving irrigation and implications for sustainable water management in an oasis: Tarim River basin of western China. Hydrology and Earth System Sciences, 11, 1777-1820, doi: 10.5194/hess-183951-2014 Zhao, M., Heinsch, F.A., Nemani, R.R., \& Running, S.W. (2005). Improvements of the MODIS terrestrial gross and net primary production global data set. Remote sensing of Environment, 95, 164-176, doi: 10.1016/j.rse.2004.12.011 Zhao, M., \& Running, S.W. (2010). Drought-induced reduction in global terrestrial net primary production from 2000 through 2009. Science 329: 940-943, doi: 10.1126/science.1192666 Zhou, J.B., Wang, C.Y., Zhang, H., Dong, F., Zheng, X.F, Gale, W., \& Li, S.X. (2011). Effect of water saving management practices and nitrogen fertilizer rate on crop yield and water use efficiency in a winter wheat-summer maize cropping system. Field Crops Research, 122, 157-163, doi: 10.1016/j.fcr.2011.03.009 Zhou, P., Huang, J., Pontius, R. G., Jr., \& Hong, H. (2014). Land classification and change intensity anal- 
ysis in a coastal watershed of Southeast China. Sensors (Basel), 14, 11640-11658. doi:10.3390/s140711640 Zimmermann, P., Tasser, E., Leitinger, G., \& Tappeiner, U. (2010). Effects of land-use and land-cover pattern on landscape-scale biodiversity in the european alps. Agriculture Ecosystems \& Environment 139, 13-22, doi: 10.1016/j.agee.2010.06.010 Zou, X., Li, Y.e., Cremades, R., Gao, Q., Wan, Y., \& Qin, X. (2013). Cost-effectiveness analysis of water-saving irrigation technologies based on climate change response: A case study of China. Agricultural Water Management, 129, 9-20, doi: 10.1016/j.agwat.2013.07.004

Table 1. Land cover reclassification scheme. The numbers refer to the land cover type codes for individual products, and the characters in parentheses are the type name abbreviations.

\begin{tabular}{lll}
\hline Land cover type & ESA CCI LC & MCD12C1 \\
\hline 1. Forest (F) & $50 / 60 / 70 / 80 / 90$ & $1 / 2 / 3 / 4 / 5$ \\
2. Shrubland (Sh) & $100 / 120$ & $6 / 7 / 8$ \\
3. Grassland (G) & $110 / 130$ & $9 / 10$ \\
4. Sparse Vegetation (SV) & 150 & 16 \\
5. Barren (B) & 200 & \\
6. Agriculture (A) & $10 / 20 / 30 / 40$ & $12 / 14$ \\
7. Urban (U) & 190 & 13 \\
8. Others (O) & $160 / 170 / 180 / 210 / 220$ & $11 / 15 / 0$ \\
\hline
\end{tabular}

Table 2. Areas converted from different natural cover to agriculture and the corresponding changes in net primary production in different new agriculture areas from 2000 to 2015.

\begin{tabular}{lllllll}
\hline & $\mathrm{F}-\mathrm{A}$ & $\mathrm{Sh}-\mathrm{A}$ & $\mathrm{G}-\mathrm{A}$ & $\mathrm{SV}-\mathrm{A}$ & $\mathrm{B}-\mathrm{A}$ & Total \\
\hline Area $(\mathrm{Mha})$ & 1.38 & 3.89 & 5.94 & 7.02 & 2.37 & 20.60 \\
$\Delta \mathrm{P}_{\text {transform }}(\mathrm{TgC})$ & -0.49 & 0.52 & 0.20 & 1.51 & 0.68 & 2.42 \\
$\Delta \mathrm{P}_{\text {estimate }}(\mathrm{TgC})$ & -6.08 & 0.39 & 0.00 & 22.89 & 7.72 & 24.92 \\
$\Delta \mathrm{P}_{\text {mean }}(\mathrm{TgC})$ & -2.02 & 1.49 & 6.88 & 13.79 & 6.85 & 26.99 \\
\hline
\end{tabular}

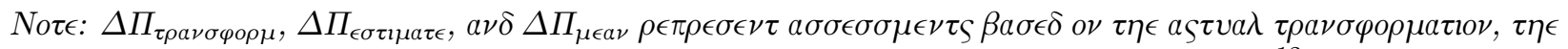

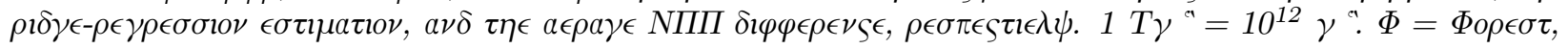

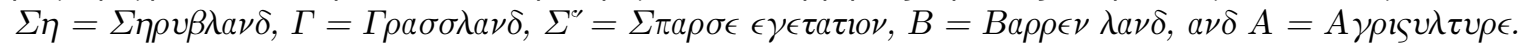

Table 3. Changes in NPP and the areas of each land cover type in drylands from 2000 to 2014, the corresponding changes in net primary production.

\begin{tabular}{|c|c|c|c|c|c|c|c|c|c|}
\hline & $\mathrm{F}$ & Sh & $\mathrm{G}$ & $\mathrm{SV}$ & B & $\mathrm{A}$ & $\mathrm{U}$ & $\mathrm{O}$ & Total \\
\hline$[?] \mathrm{NPP}\left(\mathrm{g} \mathrm{C} / \mathrm{m}^{2}\right)$ & 7 & 16 & 3 & 2 & 0 & 6 & 13 & 4 & $5 ? \gtreqless ?$ \\
\hline Area (Mha) & -10 & 3 & 7 & -1 & -23 & 13 & 12 & -1 & $0 ? i ?$ \\
\hline $\mathrm{P}_{\mathrm{Cli}}(\mathrm{Tg} \cdot \mathrm{C})$ & 44 & 163 & 30 & 15 & 0 & 69 & 2 & 8 & $329 ?$ ¿? \\
\hline $\mathrm{P}_{\text {LUCC }}(\mathrm{Tg} \cdot \mathrm{C})$ & -43 & 9 & 12 & -1 & -3 & 38 & 23 & -1 & $34 ? \gtreqless ?$ \\
\hline $\mathrm{P}_{\text {Int }}(\mathrm{Tg} \cdot \mathrm{C})$ & -1 & 1 & 0 & 0 & 0 & 1 & 1 & 0 & $2 ? \dot{\imath} ?$ \\
\hline $\mathrm{P}_{\text {Total }}(\mathrm{Tg} \cdot \mathrm{C})$ & 0 & 172 & 43 & 14 & -3 & 108 & 26 & 7 & 365 \\
\hline
\end{tabular}

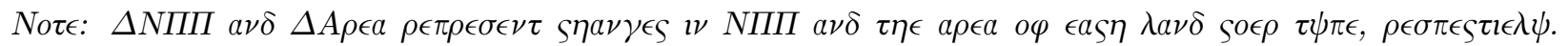

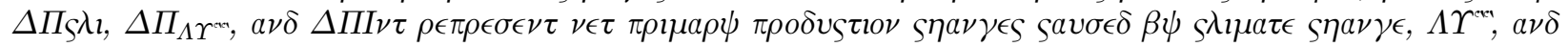

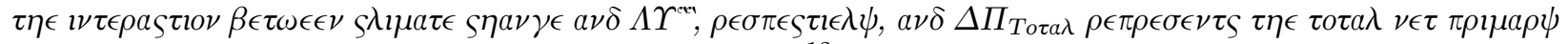

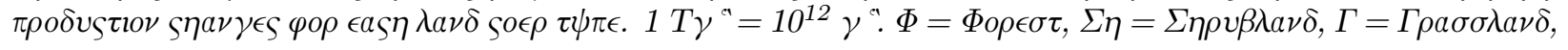




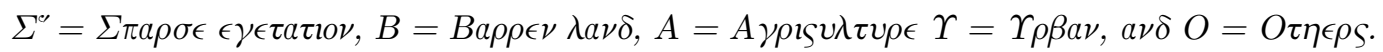
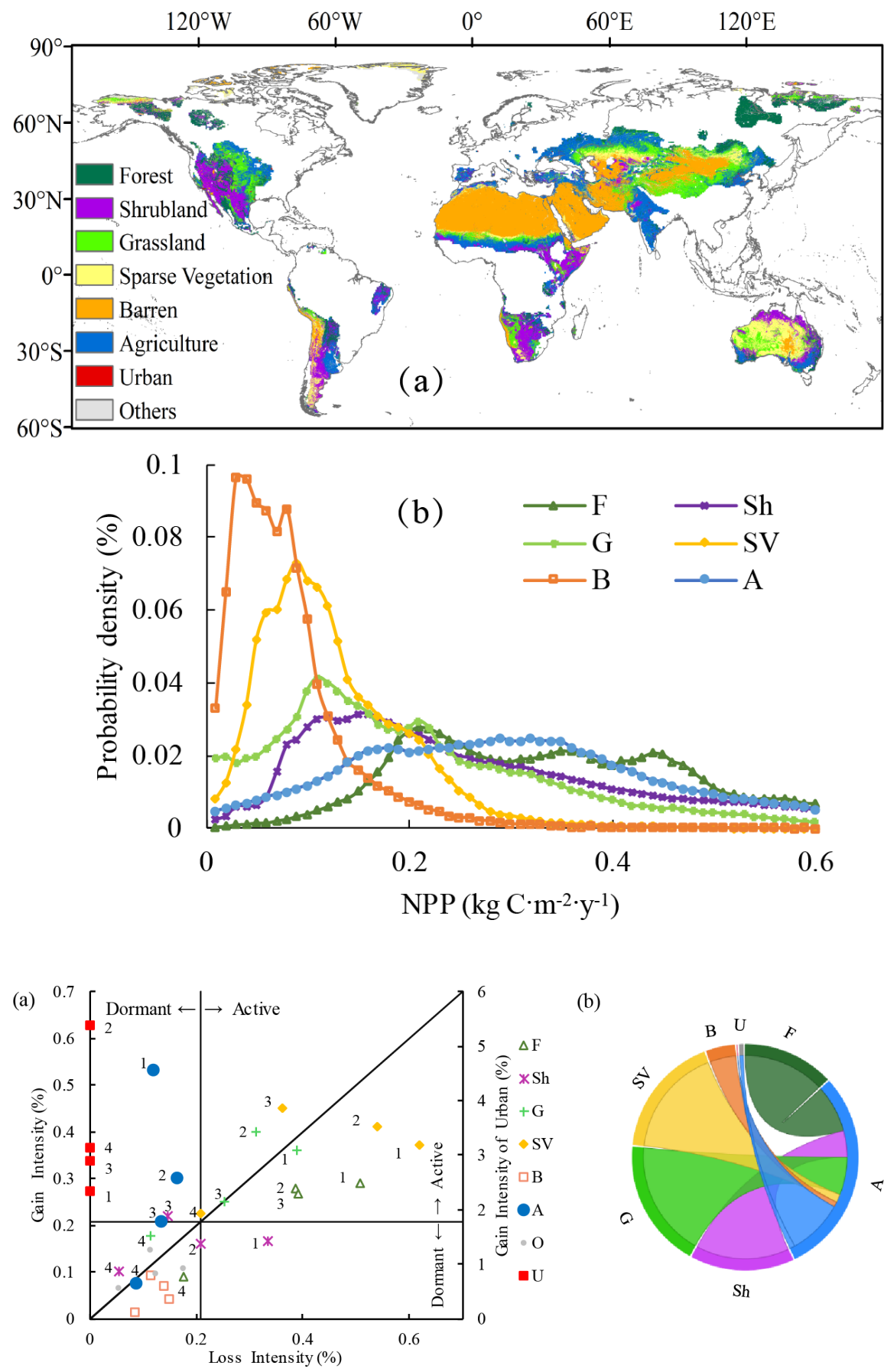

(b)

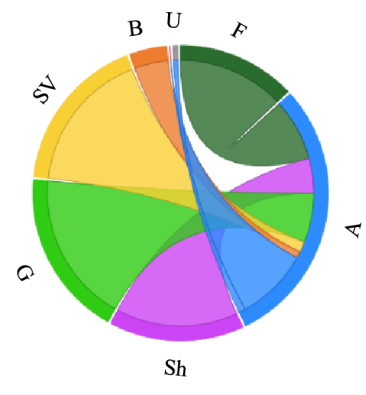



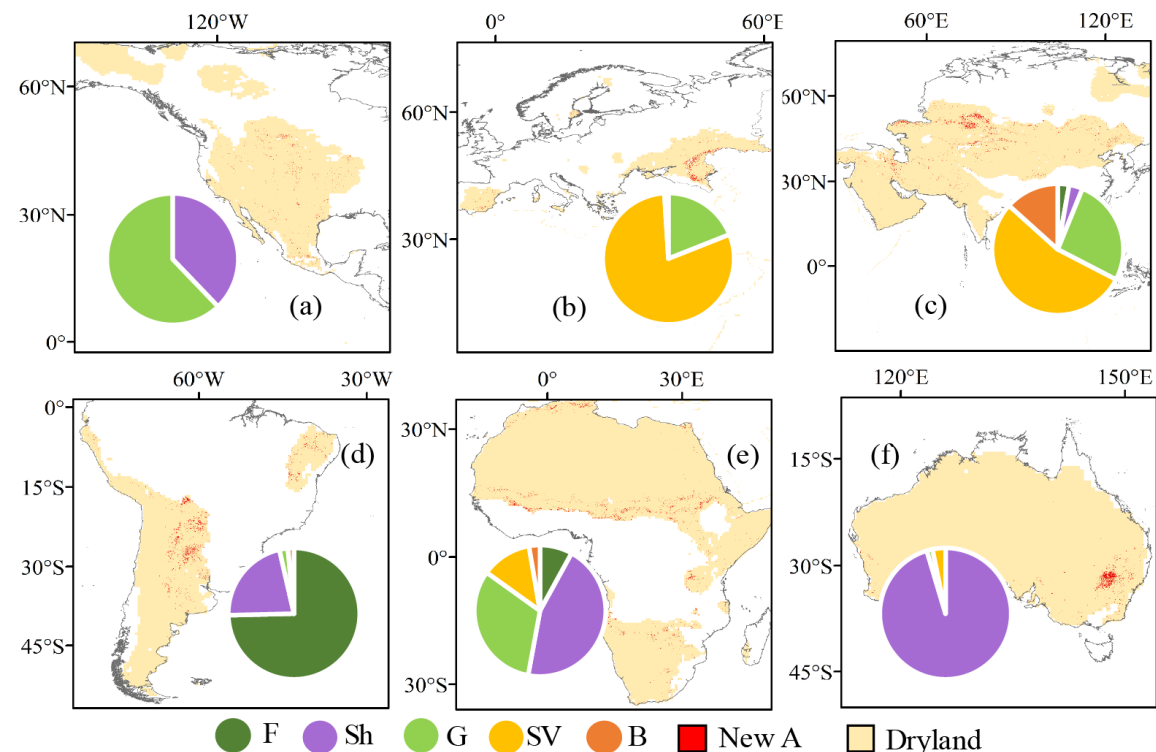

New A $\square$ Dryland 

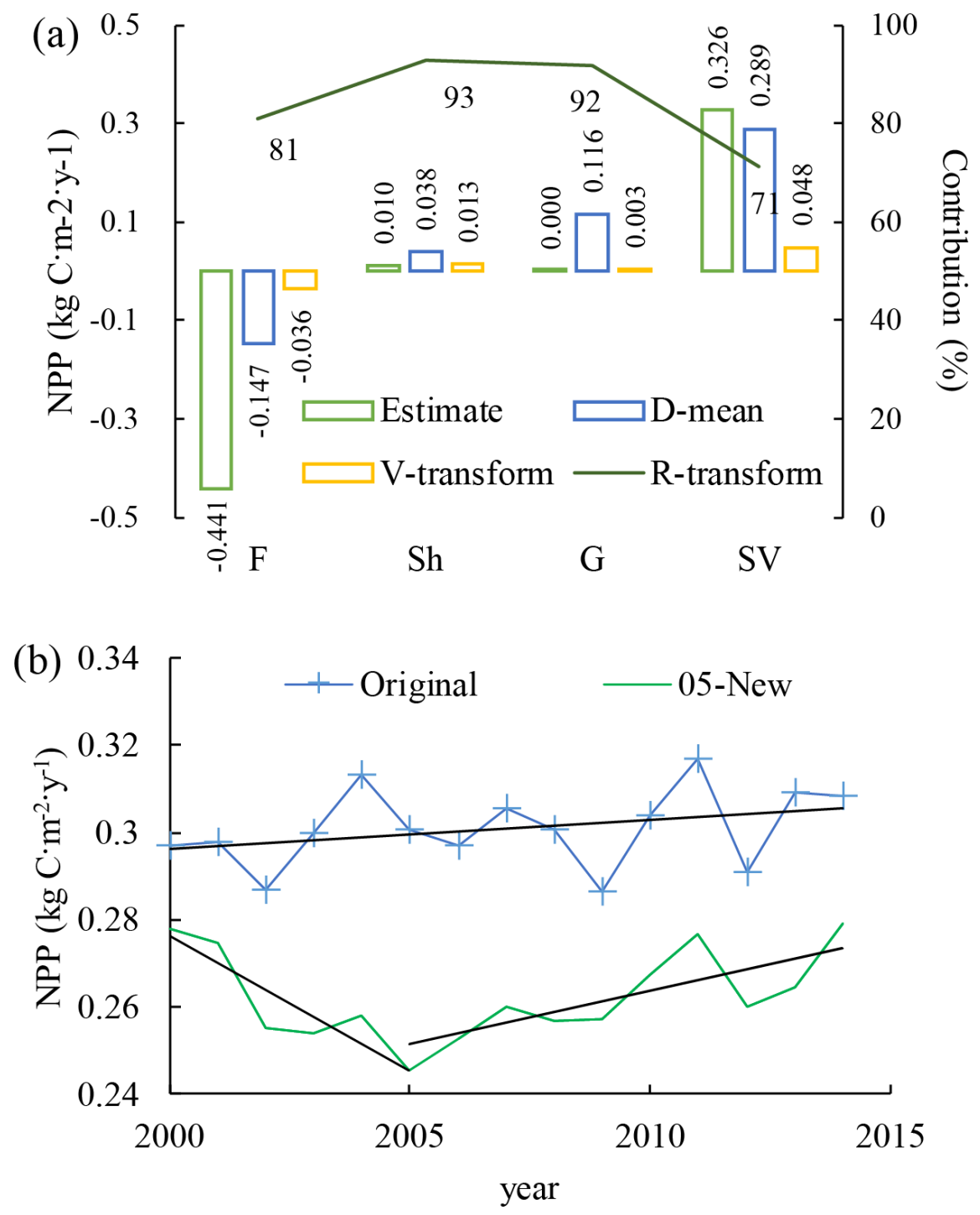